\title{
PERGESERAN BAHASA DAERAH LAMPUNG PADA MASYARAKAT KOTA BANDAR LAMPUNG
}

\author{
Nandita Wana Putri \\ Dosen di Akademi Keperawatan Panca Bhakti Bandar Lampung; \\ E-mail: nanditawana@gmail.com
}

\begin{abstract}
Lampung is one of the provinces in Indonesia which is located strategically. It is located in the south of Sumatra Island that makes Lampung as the only gateway for those who want to go to Sumatra Island. The complexity of the society in Lampung, especially in Bandar Lampung city, has an impact on the survival of indigenous people of Lampung itself. One of the effects is the waning of the indigenous languages of Lampung in the city. The aim of this study is to find out the reasons why Lampung is starting to be abandoned, to know how to use Lampung Language, to know what areas still survive in the use of Lampung Language, and to describe what efforts have been made to preserve the Lampung language in the Bandar Lampung city. The qualitative approach is used in this study. The data are obtained by applying the methods of observation, interview, and document analysis. This study found that in Bandar Lampung city Lampung language experience a language shift which then will be extinction if not preserved optimally.
\end{abstract}

Keywords: Lampung language, Language preservation, Language shift, Multilingualism

\begin{abstract}
ABSTRAK
Lampung adalah salah satu provinsi di Indonesia yang letaknya sangat strategis. Letaknya yang berada di ujung Selatan pulau Sumatera, menjadikan Lampung sebagai satu-satunya pintu gerbang bagi mereka yang ingin masuk ke Pulau Sumatera. Majemuknya komposisi masyarakat yang ada di Lampung khususnya di kota Bandar Lampung berdampak bagi kelangsungan masyarakat asli Lampung itu sendiri. Salah satu dampaknya adalah semakin memudarnya penggunaan bahasa asli daerah Lampung di kota ini. Tujuan dari makalah ini adalah untuk mengetahui alasan mengapa Bahasa Lampung mulai ditinggalkan, mengetahui bagaimana penggunaan Bahasa Lampung, mengetahui ranah-ranah apa sajakah yang masih bertahan dalam penggunaan Bahasa Lampung, dan mendeskripsikan upaya apa saja yang telah dilakukan untuk pelestarian Bahasa Lampung di kota Bandar Lampung. Penelitian ini merupakan penelitian kualitatif. Penelitian ini menggunakan tiga teknik dalam mengumpulkan data yaitu observasi, wawancara dan studi dokumen. Kesimpulan dalam makalah ini bahwa di kota Bandar Lampung, bahasa Lampung mengalami pergeseran bahasa yang kemudian akan mengalami kepunahan jika tidak dilestarikan secara optimal.
\end{abstract}

Kata kunci: Bahasa daerah Lampung, Multikultural, Pelestarian bahasa, Pergeseran bahasa 


\section{PENDAHULUAN}

Indonesia merupakan negara multikultural, yaitu negara yang memiliki berbagai keragaman suku, agama, ras, budaya dan bahasa. Seiring dengan perkembangan zaman dan era globalisasi, keanekaragaman tersebut kini terancam. Keanekaragam yang menjadi sorotan utama terutama di daerah Provinsi Lampung yaitu keanekaragaman bahasa daerah yang semakin ditinggalkan dan nyaris punah. Keanekaragaman yang ada pada masyarakat kota Bandar Lampung mengakibatkan bahasa daerah Lampung mengalami pergeseran. Pergeseran dan pemertahanan bahasa daerah menurut Sumarsono (2011) merupakan dua sisi mata uang. Fenomena ini merupakan dua fenomena yang terjadi bersamaan. Bahasa menggeser bahasa lain atau bahasa yang tak tergeser oleh bahasa lain, bahasa yang tergeser adalah bahasa yang tidak mampu mempertahankan diri. Kondisi tersebut terjadi pada saat suatu masyarakat (komunitas bahasa) memilih untuk menggunakan atau meninggalkan pemakaian suatu bahasa. Pilihan atas salah satu dari kondisi tersebut terjadi dalam rentang waktu yang panjang. Rentang waktu ini bisa mencapai lebih dari dua atau tiga generasi. Fasold (dalam Lukman: 2000) mengungkapkan bahwa pergeseran dan pemertahanan bahasa ibarat dua sisi mata uang yang tidak dapat dipisahkan satu sama lainnya. Dia merupakan hasil kolektif dari pilihan bahasa (language choice). Dalam pemertahanan bahasa, masyarakat secara kolektif menentukan untuk melanjutkan memakai bahasa yang sudah biasa dipakai. Ketika sebuah masyarakat memilih bahasa baru di dalam ranah yang semula digunakan bahasa lama, pada saat itu merupakan kemungkinan terjadinya proses sebuah pergeseran bahasa.

Bahasa daerah di Indonesia berjumlah lebih dari 700an dari total sekitar 6000 bahasa yang tersebar di seluruh dunia. Untuk jumlah bahasa daerah di Indonesia, ada peneliti yang mengatakan jumlah bahasa daerah di tanah air sebanyak 706, ada yang mengemukakan jumlah bahasa daerah sebanyak 720 bahasa dan bahkan data dari SIL (Summer Institute of Linguistics) menunjukan angka 735 bahasa daerah yang tersebar (lihat Macaryus dalam Mulyana, 2008:123-124). Dari jumlah bahasa tersebut, dapat dikelompokan dalam dua katagori besar yaitu bahasa daerah yang kuat dan bahasa daerah yang tergolong lemah. Bahasa yang kuat adalah bahasa yang dianggap masih bisa bertahan hidup dalam kurun waktu yang masih lama.Sedangkan bahasa yang lemah adalah bahasa daerah yang rentan dengan masalah-masalah yang mengkhawatirkan, 
yakni kepunahan atau kematian. Kekuatansuatu bahasa dapat dilihat dari jumlah penutur yang masih aktif menggunakan bahasanya di atas 100.000 orang. Sementara bahasa dengan jumlah penutur di bawah 100.000 orang tergolong bahasa yang lemah dan terancam mati atau punah. Bila dilihat dari jumlah penuturnya, maka bahasa-bahasa yang sangat kuat adalah bahasa Jawa, Sunda, dan Madura. Bahasa-bahasa tersebut dianggap kuat atau sehat dan akan mampu bertahan dalam waktu yang relatif lama. Meskipun penutur bahasa Jawa, misalnya, dengan penutur terbanyak dari semua bahasa daerah di Indonesia tidak melakukan transferensi bahasa, maka ketika terjadi pergantian generasi, maka bahasa ini juga tidak lepas dari kepunahan.

Bahasa Lampung adalah bahasa daerah dan sebagai bahasa ibu bagi masyarakat di Provinsi Lampung. Bahasa Lampung dibagi menjadi 2 yaitu Pepadun dan Saibatin. Perbedaan Bahasa Lampung pada letak geografis. Bahasa Lampung dengan Dialek Nyow (Pepadun) adalah bahasa yang dipergunakan oleh masyarakat Lampung di wilayah nonpesisir. Adapun Bahasa Lampung Dialek Api (Saibatin) adalah bahasa yang dipergunakan oleh masyarakat pesisir. Dengan demikian Bahasa Lampung adalah bahasa daerah yang dituturkan oleh Ulun Lampung dan juga merupakan identitas Provinsi Lampung.

Provinsi Lampung merupakan salah satu provinsi di Indonesia yang letaknya sangat strategis. Letaknya yang berada di ujung Selatan pulau Sumatera, menjadikan Lampung sebagai satu-satunya pintu gerbang bagi mereka yang ingin masuk ke Pulau Sumatera. Itulah salah satu faktor yang membuat Lampung ramai didatangi oleh para pendatang dari berbagai macam suku. Majemuknya komposisi masyarakat yang ada di Lampung tersebut, bukannya tidak berdampak bagi kelangsungan masyarakat asli Lampung itu sendiri. Terutama di Kota Bandar Lampung, salah satu dampaknya adalah semakin memudarnya penggunaan bahasa asli daerah Lampung di kota ini. Pudarnya jumlah penutur Bahasa Lampung di Kota Bandar Lampung ini dapat menyebabkan punahnya bahasa Lampung sebagai jati diri dan ciri khas daerah Lampung di kemudian hari. Bahasa Lampung sebagai salah satu dari bahasa daerah yang dituturkan di Provinsi Lampung khususnya di Kota Bandar Lampung juga mengalami permasalahan yang terkait dengan pergeseran bahasa yang mengarah pada kematian bahasa. Hal ini dapat terlihat dari semakin rendahnya tingkat penggunaan bahasa ini dalam komunikasi antar penuturnya. 
Bahasa Lampung merupakan alat komunikasi masyarakat Lampung namun pada kenyataannya Bahasa Lampung sudah jarang digunakan terutama bagi remaja. Sebagian besar hanya mengetahui Bahasa Lampung tanpa mampu menuturkannya. Suku Lampung menggunakan Bahasa Lampung hanya dalam berkomunikasi di lingkungan keluarga, sesama Suku Lampung, dan pada upacara adat. Dalam berkomunikasi dengan masyarakat pendatang, Suku Lampung menggunakan Bahasa Indonesia. Hal ini berhubungan dengan penggunaan Bahasa Lampung yang kian menurun, dengan adanya heterogenitas suku dan amalgamasi telah mempersempit ruang lingkup perkembangan Bahasa Lampung itu sendiri.

Letak provinsi Lampung yang strategis membuat arus kedatangan dan tingkat interaksi masyarakat dengan latar belakang bahasa yang berbeda sangat tinggi. Keadaan ini semakin mengharuskan setiap individu menggunakan bahasa pengantar yang dapat dimengerti oleh semua orang dengan latar belakang bahasa yang berbeda guna mencapai tujuan komunikasi yang baik. Bahasa yang dapat digunakan oleh semua orang dengan latar belakang bahasa yang berbeda tersebut adalah bahasa Indonesia. Tingginya intensitas penggunaan bahasa Indonesia tersebut menjadikan bahasa ini sebagai bahasa pemangsa untuk bahasa-bahasa daerah di provinsi Lampung khususnya di kota Bandar Lampung. Bahasa Indonesia ini sudah menguasai seluruh ranah komunikasi bukan hanya untuk penutur yang berbeda bahasa ibu, namun komunikasi antarsesama anggota etnis suku Lampung (penutur bahasa Lampung) pun sudah menggunakan bahasa Indonesia, lebih-lebih lagi di ranah keluarga yang menjadi dasar pemertahanan. Dengan kata lain, telah terjadi pergeseran bahasa (language shift) dari bahasa Lampung ke bahasa Indonesia. Sehingga penutur bahasa Lampung telah menjadi penutur multi bahasa dengan tingkat penggunaan bahasa Lampungnya yang sangat rendah (language attrition) seiring dengan ranah komunikasi yang sudah didominasi oleh bahasa Indonesia.

Dengan penjelasan di atas, maka harus adanya upaya dalam mempertahankan bahasa Lampung sangat penting untuk dilakukan. Hal ini untuk dapat melestarikan bahasa Lampung sebagai bagian dari kekayaan bahasa Nusantara, sebagai identitas masyarakat Lampung, dan sebagai alat komunikasi intraetnis dapat dipertahankan eksistensinya di tengah kuatnya dominasi bahasa lain. 
Tujuan dari makalah ini adalah untuk mengetahui alasan mengapa Bahasa Lampung mulai ditinggalkan, mengetahui bagaimana penggunaan Bahasa Lampung, mengetahui ranah-ranah apa sajakah yang masih bertahan dalam penggunaan Bahasa Lampung, dan mendeskripsikan upaya apa saja yang telah dilakukan untuk pelestarian Bahasa Lampung di kota Bandar Lampung.

\section{TEORI DAN METODOLOGI}

Teori-teori yang digunakan dalam penelitian ini yaitu antara lain terkait dengan pergeseran bahasa (Holmes, 2001) dan pemertahanan bahasa oleh Auburger (dalam Batibo, 2005). Selain itu juga digunakan teori-teori tentang sikap bahasa (language attitudes). Teori sikap bahasa digunakan dengan dasar argument bahwa suatu bahasa bertahan atau bergeser sangat ditentukan oleh sikap bahasa penutur terhadap bahasa mereka. Ketika penutur memiliki sikap bahasa yang positif, maka bahasanya akan bertahan, demikian sebaiknya jika perdapat sikap bahasa yang negative, maka bahasanya akan tergeser oleh bahasa yang dominan. Pemertahanan bahasa merupakan penggunaan sebuah bahasa secara kontinu oleh penuturnya, khususnya dalam keadaan bahasa itu berada dalam tekanan bahasa lain (Trask, 1997: 126). Penggunaan bahasa yang dimaksud bukan hanya pada tataran komunikasi verbal. Penggunaan juga bisa berupa iklan, baliho, spanduk dan lainnya. Berbeda dengan bahasa Jawa, bahasa daerah Lampung hampir tidak terlihat penggunaan pada ranah ini. Sangat jarang ada baliho atau iklan berbahasa Lampung.

Pergeseran bahasa umumnya mengacu pada proses penggantian satu bahasa dengan bahasa lain dalam repertoir linguistik suatu masyarakat. Dengan demikian, pergeseran bahasa mengacu pada hasil proses penggantian satu bahasa dengan bahasa lain (Ibrahim, 2003). Pergeseran bahasa akan terjadi hanya kalau, dan seberapa jauh, suatu guyup menghendaki untuk menghilangkan identitasnya sebagai kelompok sosiokultural yang dapat diidentifikasi sendiri demi identitas sebagai bagian dari guyup lain. Sangat sering kelompok lain itu adalah kelompok yang lebih besar yang mengontrol masyarakat tempat guyup pertama itu sebagai minoritas. Alasan perbedaan sosial yang menjadi hal utama untuk pilihan kode atau variasi dalam sebuah komunitas multilingual. Terdapat beberapa kelompok yang mempertahankan bahasa dan identitas etnik mereka dalam kondisi sosial-ekonomi yang sangat serupa dengan yang 
memengaruhi kelompok lain untuk menggeser identitas dan bahasanya. Holmes menyatakan bahwa ada dua kondisi masyarakat dengan sebuah bahasa mengalami pergeseran, yakni (a) migrant minorities, dan (b) nonmigrant communities. Kondisi pertama, pergeseran terjadi pada sebagian orang yang bermigrasi ke suatu tempat yang berbeda bahasanya; kondisi kedua pergeseran terjadi pada orang-orang bukan komunitas imigran (penduduk asli). Jadi, perubahan politik, ekonomi, dan sosial yang terjadi secara langsung dalam komunitas dapat menyebabkan perubahan linguistik juga. Menurut Holmes (2000:57), pergeseran bahasa (language shifting) atau pemertahanan bahasa (language maintainance) dapat terjadi di berbagai sektor kehidupan, misalnya ekonomi, sosial, budaya, pendidikan, politik, pemerintahan dan sebagainya. Kedua peristiwa ini tentunya diikuti dengan bukti-bukti penggunaan bahasa masyarakat penuturnya. Kesadaran akan pendidikan, peningkatan kondisi ekonomi, dan mobilitas penduduk yang tinggi ternyata berpengaruh pada penggunaan bahasa sehari-hari.

Menurut Fasold (1984: 213-214) pergeseran dan pemertahanan bahasa merupakan hasil dari proses pemilihan bahasa dalam jangka waktu yang sangat panjang. Pergeseran bahasa menunjukkan adanya suatu bahasa yang benar-benar ditinggalkan oleh komunitas penuturnya. Hal ini berarti bahwa ketika pergeseran bahasa terjadi, anggota suatu komunitas bahasa secara kolektif lebih memilih menggunakan bahasa baru daripada bahasa lama yang secara tradisional biasa dipakai.

Pergeseran bahasa umumnya mengacu pada proses penggantian satu bahasa dengan bahasa lain dalam repertoir linguistik suatu masyarakat (Ibrahim, 2003). Pergeseran bahasa (language shift) menyangkut masalah pengggunaan bahasa oleh seorang penutur atau sekelompok penutur yang bisa terjadi sebagai akibat perpindahan dari suatu masyarakat tutur ke masyarakat tutur lain. Beberapa kondisi cenderung dihubung-hubungkan terhadap pergeseran bahasa. Kondisi yang paling mendasar barangkali adalah kedwibahasaan (bilingualism). Tetapi patut diperhatikan dengan seksama bahwa kedwibahasaan ini bukanlah satu-satunya faktor yang menyebabkan pergeseran bahasa. Kedwibahasaan tidak dengan serta merta menyebabkan pergesaran bahasa, meskipun ini merupakan salah satu syarat terjadinya pergeseran bahasa. Kasuskasus pergeseran bahasa hampir seluruhnya terjadi melalui alih generasi (intergenerasi). Maksudnya adalah pergeseran bahasa memerlukan waktu lebih dari satu generasi. Chaer dan Agustina (2004:142) mengemukakan bahwa pergeseran bahasa menyangkut 
masalah penggunaan bahasa oleh seorang penutur atau sekelompok penutur yang bisa terjadi sebagai akibat perpindahan dari satu masyarakat tutur ke masyarakat tutur lain. Dengan kata lain, pergeseran bahasa akan terjadi bila seorang atau sekelompok orang penutur bahasa tertentu pindah ke tempat baru, yang mana bahasanya berbeda, dan bercampur dengan mereka. Pendatang atau kelompok baru ini harus menyesuaikan diri dengan menanggalkan bahasanya sendiri, lalu menggunakan bahasa penduduk setempat dan terjadi selama beberapa generasi. Apabila satu kelompok baru datang ke tempat lain dan bercampur dengan kelompok setempat, maka akan terjadilah pergeseran bahasa (language shift). Kelompok pendatang ini akan melupakan sebagian bahasanya dan 'terpaksa' memperoleh bahasa setempat. Alasannya karena kelompok pendatang ini harus menyesuaikan diri dengan situasi baru tempat mereka berada. Selanjutnya kelompok pendatang ini akan mempergunakan dua bahasa, yaitu bahasa nasional dan bahasa daerah setempat (Alwasilah, 1993). Sedangkan Sumarsono dan Partana (2002) mengungkapkan bahwa pergeseran bahasa berarti, suatu komunitas meninggalkan suatu bahasa sepenuhnya untuk memakai bahasa lain. Bila pergeseran sudah terjadi, para warga komunitas itu secara kolektif memilih bahasa baru.

Secara sederhana dapat dikatakan bahwa pergeseran bahasa itu terjadi ketika masyarakat (komunitas bahasa) memilih suatu bahasa baru untuk mengganti bahasa sebelumnya. Dengan kata lain, pergeseran bahasa itu terjadi karena masyarakat bahasa tertentu beralih ke bahasa lain, biasanya bahasa domain dan berprestise, lalu digunakan dalam ranah-ranah pemakaian bahasa yang lama. Contoh pergeseran bahasa pada golongan imigran kecil.

Menurut Nasution, dkk (2008) Bahasa Lampung adalah bahasa daerah dan sebagai bahasa ibu bagi masyarakat di Provinsi Lampung. Bahasa Lampung dibagi menjadi 2 yaitu Pepadun dan Saibatin. Perbedaan Bahasa Lampung terletak pada perbedaan geografis. Bahasa Lampung dengan Dialek Nyow (Pepadun) adalah bahasa yang dipergunakan oleh masyarakat Lampung di wilayah nonpesisir. Adapun Bahasa Lampung Dialek Api (Saibatin) adalah bahasa yang digunakan oleh masyarakat pesisir. Sedangkan masyarakat yang tinggal di Kota Bandar Lampung ialah masyarakat yang multikultural. Hal ini dibuktikan dari letak geografis Lampung yang berada di ujung Selatan pulau Sumatera, menjadikan Lampung sebagai satu-satunya pintu gerbang bagi mereka yang ingin masuk ke Pulau Sumatera. Itulah salah satu faktor yang membuat 
Lampung ramai didatangi oleh para pendatang dari berbagai macam suku. Majemuknya komposisi masyarakat yang ada di Lampung tersebut, bukannya tidak berdampak bagi kelangsungan masyarakat asli Lampung itu sendiri. Terutama di Kota Bandar Lampung, salah satu dampaknya adalah semakin memudarnya penggunaan bahasa asli Lampung di kota ini.

Penelitian ini dilakukan hanya di kota Bandar Lampung dengan jumlah penutur bahasa daerah yang semakin sedikit. Lokasi ini dipilih dengan alasan bahwa di kota Bandar Lampung sendiri, meskipun terdapat penutur bahasa Lampung namun tidak berjumlah besar serta merupakan kota dengan tingkat mobilitas masyarakat pendatang sangat tinggi. Masyarakat kota Bandar Lampung merupakan masyarakat yang plural. Pluralism ini mendorong intensitas penggunaan bahasa Indonesia sangat tinggi, sehingga bahasa Lampung semakin lemah dalam penggunaannya bila dibandingkan dengan daerah lain yang berbahasa Daerah Lampung. Meskipun kecil jumlah penuturnya, peneliti menganggap masih cukup kuat karena tingkat interaksi dengan dunia luar masih sangat rendah. Penelitian tentang Pergeseran Bahasa Lampung ini merupakan penelitian kualitatif dengan informan yang variatif. Oleh karena itu penentuan informan dilakukan dengan teknik purposive sampling. Dengan harapan bahwa semua populasi yang variatif dapat terwakili dalam pemerolehan informasi yang penting yang tidak dapat dilakukan dengan cara yang lain (lihat Alwasilah, 2008:146). Penelitian menggunakan tiga teknik dalam mengumpulkan data yakni observasi, wawancara dan studi dokumen. Ketiga teknik ini akan saling mendukung dalam memberikan informasi yang valid dan reliable. Peneliti menggunakan teknik analysis data deskritptif-kualitatif, yakni peneliti akan mendeskripsikana data-data atau faktafakta pergeseran bahasa Lampung dari hasil observasi, wawancara dan studi dokumen.

\section{TEMUAN DAN PEMBAHASAN}

Pakar bahasa dari Universitas Negeri Sebelas Maret (UNS) Solo, Prof. Dr. H. Edi Subroto, menyatakan bahwa dari hasil penelitian yang dilakukan Jurusan Bahasa UNS menyebutkan bahwa bahasa daerah yang terancam punah bisa mencapai 700 bahasa. "Dari hasil penelitian kami, jumlah bahasa daerah yang rawan punah sangat banyak. Sedikitnya 700 bahasa daerah bisa punah dalam waktu sesaat jika tidak ada upaya untuk merawatnya," ungkapnya. (Lampung Post, 4-4) 
Salah satu penyebab lunturnya bahasa daerah, lanjut Edi, adalah fenomena ketertarikan generasi muda mempelajari bahasa asing dibandingkan dengan bahasa daerah. Mereka juga enggan untuk menggunakan bahasa daerahnya untuk komunikasi keseharian. Demikian pula dengan masyarakat kota Bandar Lampung yang merasa derajat bahasa Lampung tidak begitu tinggi sehingga mereka enggan untuk menggunakan bahasa Lampung dalam bahasa sehari-hari mereka.

Pemerhati bahasa Lampung, Agus Sri Danardana, mengemukakan jumlah penutur bahasa Lampung di wilayah ini semakin turun dan diperkirakan jumlahnya hanya sekitar 1,19 juta orang. Jumlah penutur bahasa daerah yang menurun itu berdasarkan jumlah penduduk asli Lampung saat ini. "Jumlah penuturnya semakin berkurang mengingat banyak warga asli yang tak lagi mengenalkan penggunaan bahasa ibu ke anak anak mereka, serta mengalihkannya ke penggunaan bahasa Indonesia," ujar mantan Kepala Kantor Bahasa Provinsi Lampung tersebut. Hal itu menjelaskan bahwa saat ini sudah jarang keluarga di Lampung yang memperkenalkan dan membiasakan anak-anaknya untuk menggunakan bahasa Lampung dalam kehidupan sehari-hari.

Selain itu, faktor banyaknya pendatang dari luar Lampung membuat bahasa asli Lampung tergeser. Pendatang yang kebanyakan berasal dari Jawa menggunakan bahasa Indonesia sebagai alat komunikasi mereka dengan penutur asli bahasa Lampung sehingga bahasa yang berkembang dan akhirnya dominan dalam masyarakat Lampung adalah bahasa Indonesia.

Bahasa Lampung awalnya dipergunakan di daerah keresidenan Lampung, di daerah Komering yang termasuk dalam keresidenan Palembang juga di daerah Krui. Menurut Van der Tuuk, dalam Bambang Suwondo (1983), bahasa Lampung dapat dibagi dalam dua induk dialek yaitu dialek Abung dan dialek Pubian. Namun dalam buku yang sama, Dr. Van Royen membagi bahasa daerah Lampung itu dalam dua dialek yaitu "dilek nyow" dan "dialek api". Tapi sebenarnya dalam bahasa sehari-hari kita dapat membedakan antara dialek yang ucapannya banyak memakai kata-kata "a" dan dialek yang banyak memakai kata-kata "o". Dialek "a" digolongkan dalam "Belalau", sedangkan dialek "o" atau "ou" digolongkan dalam dialek Abung. Sebagai contoh, Dialek "a": Kak saka ngakalinding haga bancong nyak rabai Mak hina gering nuntun bungan di tangkai. Dialek "o": Kak sakou ngekelinding agou bacceng nyak ngabai Mak inou atei buguh ngebekem di tangkai. Dalam bahasa Indonesia artinya adalah: "Sudah 
lama mendekat terus terang saya takut, tak demikian hati ingin menggenggam bunga di tangkai".

Sebenarnya antara kedua dialek itu tidak begitu banyak memiliki perbedaan. Jika dihitung masyarakat penggunanya, dialek "a" lebih banyak dipakai daripada dialek "o". Selain antara kedua dialek tersebut, terdapat juga dialek campurannya "a" dan "o" yang terbentuk dari pengaruh setempat lalu menjadi dialek "e". Dialek ini nampak pada bahasa Lampung Kayu-agung.

Jika kita menggabungkan hasil penelitian Walker dan Vam Royen, maka bahasa daerah Lampung bisa kita bagi dalam dialek langsung dengan perbedaan adat istiadat masyarakat, sebagai berikut:

- Lokasi pengguna dialek "a" atau Belalau berada di tengah masyarakat Beradat Peminggir di daerah; Melinting Maringgai, Pesisir Raja Basa, Pesisir Teluk, Pesisir Semangka, Pesisir Krui, Belalalu/Ranau, Komering, Kayu-agung. Pengguna lainnya adalah masyarakat Beradat di daerah; Way-kanan, Sungkay, Pubian.

- Sementara lokasi pengguna dialek "o" atau Abung, hanya berada di tengah masyarakat Beradat Pepadun yang tinggal di daerah Abung dan Tulangbawang.

Bahasa Lampung, baik dialek "a" maupun "o", tidak memiliki tingkatantingkatan perbedaan dalam pemakaian bahasa seperti "undak usuk basa" dalam bahasa Sunda. Hanya cukup mengganti kata ganti orang dalam pembicaraan antar sesama orang muda, antar orang yang muda dengan orang yang tua, atau antar sesama orang tua. Untuk menunjukkan kesopanan dalam pembincangan dengan orang yang tua, cukup dengan melemahkan intonasi atau tekanan pengujaran.

Kini bahasa Lampung hanya menjadi bahasa komunikasi dalam kerabat yang terbatas pemakaianya, yaitu hanya dipakai di rumah, di kampung-kampung penduduk asli antar sesamanya, dan di waktu permusyawarahan adat, hal ini sangat disayangkan. Bahkan bahasa Lampung belum bisa eksis dalam perkembangan teknologi, karena software kamus Bahasa Lampung-Indonesia belum mendapat banyak sumbangsih entri data dari masyarakat penggunanya.

Padahal menurut Prof Chaedar Alwasilah, guru besar UPI Bandung, pembiasaan penggunaan bahasa daerah dalam komunikasi sehari-hari dan dalam pengajaran bahasa terhadap anak di Sekolah Dasar dan Menengah, sangatlah penting. Hal ini dikarenakan 
dalam bahasa tidak hanya terdapat aspek komunikasi saja, melainkan menyangkut juga aspek-aspek di dalam budaya daerah tersebut, seperti pandangan hidup, ilmu pengetahuan, seni sastra dan lain-lain. Dengan kata lain, jika sebuah bahasa telah kehilangan penggunanya, maka hilang pula kebudayaan pengguna bahasa tersebut.

Bahasa Lampung sudah sangat jarang digunakan oleh masyarakat Lampung dalam situasi informal yang santai karena mereka cenderung menggunakan bahasa Indonesia sebagai bahasa sehari-hari mereka. Meskipun demikian, terkadang bahasa Lampung masih bertahan dan digunakan dalam situasi-situasi tertentu. Salah satunya adalah pada saat upacara adat pernikahan. Itupun tidak satu acara penuh menggunakan bahasa Lampung dari awal hingga selesai. Bahasa Lampung biasanya hanya diselipkan pada saat prosesi pemberian gelar untuk kedua mempelai. Di luar itu, keseluruhan acara menggunakan bahasa Indonesia.

Dari hasil observasi yang dilakukan terdapat beberapa faktor yang menyebabkan pergeseran bahasa daerah Lampung. Berdasarkan hasil-hasil yang telah diamati di berbagai tempat di kota Bandar Lampung, faktor-faktor tersebut seperti loyalitas bahasa, konsentrasi wilayah pemukiman penutur, pemakaian bahasa pada ranah tradisional sehari-hari, kesinambungan peralihan bahasa-ibu antargenerasi, pola-pola kedwibahasaan, mobilitas sosial, sikap bahasa dan lain-lain. Selain itu juga dapat berupa kekuatan kelompok mayoritas terhadap kelompok minoritas, kelas sosial, latar belakang agama dan pendidikan, hubungan dengan tanah leluhur atau asal, sikap kelompok mayoritas terhadap kelompok minoritas, perkawinan campur, kebijakan politik pemerintah terhadap bahasa dan pendidikan kelompok minoritas, serta pola pemakaian bahasa.

Sekolah sering juga dituding sebagai faktor penyebab bergesarnya bahasa ibu. Hal ini dikarenakan sekolah biasanya mengajarkan bahasa asing kepada anak-anak. Pergerseran bahasa juga dapat diamati dibeberapa sekolah di kota Bandar Lampung. Kurikulum pada sekolah-sekolah di Lampung masih memasukkan bahasa Lampung dalam pelajaran Muatan Lokal sebagai bahasa daerah yang harus dipelajari murid hingga tingkatan SMP. Untuk tingkatan SMA, bahasa Lampung sudah tidak lagi ada di dalam kurikulumnya. Namun dapat dilakukan usaha seperti menciptakan kegiatan yang kaya akan penggunaan bahasa Lampung dalam pembelajaran bahasa Lampung di sekolah adalah hal yang sangat memungkinkan untuk mempertahankan bahasa 
Lampung dan agar bahasa Lampung semakin dicintai oleh penutur maupun pembelajarnya. Kegiatan-kegiatan pengguanaan bahasa lampung dapat dilakukan pada saat jam pelajaran, yaitu: sebelum pembelajaran atau pun ketika jeda waktu belajar. Beberapa kegiatan yang dapat dilakukan pada saat tersebut adalah: menyanyi, bercerita, berpantun, pertunjukan satu menit, tunjukkan dan ceritakan (show and tell), puisi, cerita lucu, kuis, dan tebak-tebakkan.

Sebagian masyarakat di daerah Lampung masih menggunakan Bahasa Lampung di dalam keluarga sebagai alat komunikasi keluarga. Mereka menggunakan Bahasa Lampung dan menciptakan suatu komunitas kecil untuk menggunakan bahasa Lampung sebagai percakapan sehari-hari. Hal ini berarti bahwa setiap anggota keluarga didorong untuk melakukan pemantapan kedwibahasaan dikarenakan mereka harus menguasai berbagai bahasa.

Festifal seni dan budaya Lampung telah rutin digelar setiap tahunnya dalam Festival Krakatau. Dalam festival ini diselenggarakan berbagai macam lomba mulai dari tari, pantun, puisi, menyayi, dsb. Dalam hal ini masyarakat tidak hanya dituntut untuk mengikuti lombanya saja namun juga dituntut untuk dapat berdiskusi dengan menggunakan bahasa lampung.

Menurut guru besar ilmu bahasa Universitas Indonesia (UI) Multamia Lauder dalam Kongres Bahasa Daerah Indonesia di Bandar Lampung, November 2007, saat ini tercatat hanya 13 bahasa daerah yang penuturnya (orang yang terus menggunakannya) lebih dari 1 juta orang. Ke 13 bahasa daerah itu adalah bahasa Jawa, bahasa Sunda, bahasa Minangkabau, bahasa Madura, bahasa Bugis, bahasa Makasar, bahasa Batak, bahasa Melayu, bahasa Aceh, bahasa Lampung, bahasa Rejang (Bengkulu), bahasa Sasak, dan bahasa Bali. (okezone.com/12 November 2007). Beruntung, bahasa Lampung termasuk satu dari 13 bahasa tersebut sehingga masih termasuk kategori aman. Sedangkan menurut ahli bahasa, kalau tidak dilestarikan, bahasa Lampung akan punah dalam tempo lebih kurang 70 tahun mendatang. Oleh karena itu, dilakukan berbagai upaya untuk melestarikan bahasa Lampung dengan membuat Undang-Undang dan Perda, di antaranya, dan yang paling konkret adalah dengan mengajarkan bahasa Lampung di sekolah-sekolah. Masalahnya, upaya pelestarian bahasa Lampung tidak cukup hanya dengan membuat Undang-Undang, Peraturan Daerah dan mengajarkan bahasa tersebut di sekolah. Untuk itu perlu ada tindakan konkret lainnya. Untuk 
mencegah punahnya bahasa Lampung diperlukan sebuah tindakan konkret yang bukan hanya sekadar Undang-Undang dan Peraturan Daerah. Misalnya dengan menciptakan gerakan "Bangga Berbahasa Lampung" dimulai dengan mewajibkan PNS dan pejabat berbahasa Lampung dalam dinas dan mewajibkan penggunaan bahasa Lampung di setiap sektor layanan publik sehari-hari.

Pemerintah Lampung Tengah (Lamteng) menggagas peraturan daerah yang mewajibkan penggunaan bahasa Lampung di lingkungan pemda setiap seminggu sekali. Ini bertujuan memasyarakatkan penggunaan bahasa Lampung yang perlahan kini mulai tersisihkan. "Kami tengah berkonsultasi dengan tokoh-tokoh adat untuk memperjuangkan ini menjadi perda. Idenya, setiap hari Jumat, di kantor-kantor, diwajibkan memakai bahasa Lampung untuk percakapan," ungkap Bupati Lamteng, Mudiyanto Thoyib. Ide mewajibkan penggunaan bahasa Lampung ini didasari kenyataan pahit bahwa Bahasa Lampung lambat laun tidak lagi dipergunakan sebagai bahasa percakapan sehari-hari. Kalau pun ada, itu pun fungsinya hanya sapaan. Kondisi ini jauh berbeda dengan daerah lainnya misalnya Sumatera Selatan atau Jawa di mana bahasa daerah masih aktif dipergunakan. Dengan makin seringnya berkomunikasi dengan bahasa Indonesia, secara perlahan penggunaan Bahasa Lampung oleh orang Lampung sendiri makin berkurang bahkan cenderung ditinggalkan. Sementara para pendatang yang bisa jadi punya animo untuk mempelajarinya, karena lebih sering diajak berbicara memakai bahasa Indonesia, maka kecil sekali peluangnya untuk bisa belajar dan cepat menguasai serta mempergunakannya. Yang terjadi kemudian, bukan bahasa Indonesia sebenarnya yang dipakai sebagai bahasa pergaulan di Lampung, melainkan Bahasa Betawi. Sehingga menjadi hal yang aneh dan nyeleneh, karena yang terdengar orang-orang berbicara memakai bahasa Betawi tapi logat Lampungnya masih kentara (begitu kental). Dengan lebih seringnya bahasa Betawi yang dipakai ketimbang bahasa Lampung, khususnya di daerah perkotaan (ibukota kabupaten/kota) seperti Bandar Lampung, Metro, Kotabumi, Bukitkemuning, bahkan Liwa, menimbulkan kekhawatiran Bahasa Lampung terancam punah.

\section{SIMPULAN}

Berdasarkan pembahasan dalam makalah ini dapat ditarik kesimpulan bahwa Bahasa Lampung mengalami pergeseran bahasa yang kemudian akan mengalami 
kepunahan jika tidak dilestarikan secara optimal. Hal ini disebabkan karena masyarakat Lampung asli bukanlah sebagai mayoritas, kenyataan menunjukkan bahasa Lampung tidak menjadi tuan rumah di daerah sendiri. Orang Lampung tidak percaya diri memakai bahasa Lampung dalam berkomunikasi, terlihat juga orang Lampung asli tidak mampu memengaruhi pendatang menggunakan bahasa Lampung. Jika ini terus terjadi, tentu saja bahasa Lampung akan menjadi bahasa yang ditinggalkan oleh penutur.

Upaya pemertahanannya pun masih terpusat pada ranah pendidikan. Seharusnya semua ranah juga harus disentuh, yakni pada ranah keluarga dan ranah masyarakat. Setelah dipelajari di sekolah sebagai bahan pelajaran, anak didik juga menggunakannya dalam komunikasi sesama anggota keluarga di rumah dan juga di lingkungan sosial, terutama pada keluarga dan lingkungan sosial yang masih aktif berbahasa Lampung. Masyarakat dan pemerintah sudah menyadari betapa pentingnya upaya pemertahanan bahasa Lampung yang sudah tergolong bahasa yang lemah. Namun tindakan pemertahanannya masih sebatas sebagai bahan ajar. Semestinya pemerintah sebagai lembaga penanggung jawab semakin intens dengan mengadakan kegiatan yang bernuansa bahasa Lampung, sebagai media aplikatif hasil pengajaran bahasa Lampung di sekolah. Semua elemen, yakni pemerintah, pendidik dan masyarakat, harus bekerja sama, dan berkontribusi dalam pemertahanan bahasa Lampung. Saling mendukung satu dengan yang lain sehingga bahasa Lampung terhindar dari bahaya kepunahan, demikian juga fungsi-fungsi bahasa Lampung dalam kehidupan sosial budaya dapat dimanfaatkan sebagaimana mestinya. Termasuk penanaman nilai-nilai karakter.

\section{DAFTAR PUSTAKA}

Alwasilah, A. C. (1993). Linguistik suatu pengantar. Bandung: Angkasa.

Arsandi, D. (2013). Menggalakkan bahasa lampung di lingkungan kampus.

Batibo, H. (2005). Language decline and death in Africa: causes, consequences, and challenges. Toronto: Multilingual Matters Ltd.

Chaer, A., \& Leonie, A. (2004). Sosiolinguistik: perkenalan awal. Edisi Revisi. Jakarta: PT. Rineka Cipta.

Fasold, R. W. (1984). The sociolinguistics of society. Oxford: Blackwell Publishers.

Holmes, J. (2001). An introduction to sociolinguistics. United Kingdom: Longman Group. 
http://regional.kompas.com/read/2010/06/28/1940171/Pemda.Lamteng.Gagas.Perda.Ba hasa.Lampung.

http://www.academia.edu/5460518/BAHASA_DAERAH_LAMPUNG.

http://zabidiyakub.blogspot.com/2014/01/bahasa-lampung-terasing-di-rumahnya.html

Katubi, O. (2006). Sikap penutur jati bahasa Lampung. Pusat Penelitian dan Kebudayaan (PMB)-LIPI.

Koran Lampung Post. (2014). Bahasa daerah Lampung yang hampir punah. 4 Maret. Halaman 15. Lampung.

Sumarsono \& Paina, P. (2002). Sosiolinguistik. Yogyakarta: Penerbit Sabda.

Trask, R. L. (1997). A Student's Dictionary of Language and Linguistics. London: Arnold, A Member of the Hodder Headline Group. 